\title{
S5ynthesis
}

International Scientific Conference of IT and Business-Related Research

\section{UTICAJ LJUDSKIH RESURSA NA USPEŠNO POSLOVANJE HOTELSKIH PREDUZEĆA}

\section{THE IMPACT OF HUMAN RESOURCES ON SUCESSFUL HOTEL MANAGEMENT}

\author{
Mirjana Šekarić ${ }^{1}$, Nenad Stanić ${ }^{1}$, Marina Kostić ${ }^{2}$, Jelena Šekarić Sotirovski ${ }^{3}$ \\ ${ }^{1}$ Univerzitet Singidunum, Danijelova 32, Beograd, Srbija \\ ${ }^{2}$ Montenegro Art D.O.O., Budva, Crna Gora \\ ${ }^{3}$ Credit Agricole S.A. A.D. Braće Ribnikar 4-6, Novi Sad, Srbija
}

\begin{abstract}
Apstrakt:
Tema ovog rada su ljudski resursi i način na koji menadžment svojim savremenim pogledom na rukovođenje u okviru organizacione strukture doprinosi uspehu hotelskih preduzeća. Ljudski resursi su nezamenljiv faktor kada je u pitanju zadovoljstvo klijenata uslugom i tretmanom, a savremeni uslovi poslovanja hotelskih preduzeća zahtevaju od menadžmenta potpuno nov pristup rukovođenja. Nije dovoljan samo formalni autoritet koji proističe iz njihove moći koju distribuiraju na niže instance. Uslovi tržišta nameću menadžmentu da ima viziju na duži rok, da bude inspirator novih ideja, da zaposlene inspiriše da bolje i produktivnije rade na svom radnom mestu, time što će ih motivisati, napraviti dobru atmosferu na poslu i nagraditi svaku dobru ideju. Kompanije stoga pribegavaju mnogim aktivnostima u sektoru ljudskih resursa i time stiču konkurentsku prednost koja omogućava bolju poziciju na turbulentnom tržištu.
\end{abstract}

\section{Ključne reči:}

ljudski resursi, hotelska preduzeća, menadžment.

\section{UVOD}

Turizam je grana privrede u kojoj ljudski resursi imaju glavnu ulogu u kreiranju dobre poslovne politike. Ljudski resursi u hotelijerstvu svojom efikasnošću postižu kvalitet u uslugama, čime je zadovoljstvo gosta prednost nad konkurencijom. Ukoliko menadžer, stručno i na pravi način, ostvari dobru koordinaciju među kadrovima u podizanju kvaliteta usluga koje se pružaju klijentima, sa uspehom može da zauzme dobre pozicije na tržištu i stekne prednosti nad konkurencijom. Odlučujuće za kvalitet poslovnog uspeha u hotelijerstvu je kvalitetno upravljanje ljudskim resursima, jer samo kvalitetom se može doći do željene pozicije na tržištu.

"Proces upravljanja ljudima je veoma odgovoran, dinamičan, složen i višedimenzionalan. Menadžment ljudskih resursa treba da neutrališe negativne osobine zaposlenih, a one pozitivne da prepozna, aktivira i usmeri na pravi način. Menadžeri žele da dobiju najbolje od ljudi sa kojima rade. Njihov cilj je sinergija" (Čerović, 2011).

Ljudi su ključni poslovni resurs koji zahteva više znanja i umeća nego upravljanje drugim resursima, i ima izuzetan značaj za organizacionu uspešnost (Stefanović \& Blagojević, 2009). Za obezbeđivanje optimalnog funkcionisanja hotelskih preduzeća ljudski resursi predstavljaju ključni faktor od čijeg kvaliteta zavisi i kvalitet usluga. Zato uspeh kompanije ne zavisi samo od ulaganja u tehnološku modernizaciju, već i od ulaganja u obrazovanje ljudskih resursa. Samo obrazovani i stručni kadrovi mogu da budu faktor konkurentske prednosti.

\section{Abstract:}

This paper examines the contribution of human resources and management that are using contemporary methods to achieve successful business performances. Human resources are an indispensable factor affecting customer satisfaction with the services provided, while modern hotel business requires that the management assumes a completely new approach. The formal authority that the management distributes to lower organizational levels is not sufficient. Contemporary market conditions require that the management has a long-term vision, incites new ideas, encourages employees to be more productive at their workplace, by motivating them, creating a good working atmosphere and rewarding every good idea. Thus, the companies resort to numerous activities in the human resources sector, thereby gaining a competitive advantage that secures them a better position in the turbulent market.

\section{Key words:}

human resources, hotels, management.

\section{ZNAČAJ LJUDSKIH RESURSA ZA HOTELIJERSTVO}

Za uspešno poslovanje $\mathrm{u}$ hotelijerstvu i njegovo dobro pozicioniranje na tržištu glavnu ulogu ima ljudski potencijal. Samo kvalitet zaposlenih može da bude faktor konkurantske prednosti, jer su ostali faktori svima dostupni. Zato savremena hotelska preduzeća zapošljavaju kvalitetne kadrove i ulažu u njihovo obrazovanje, znajući vrednost intelektualnog kapitala i time menjajući poslovnu filozofiju od tradicionalnog ka fleksibilnijem menadžmentu ljudskih resursa.

Hotelijerstvo je specifična delatnost gde ljudski rad zauzima najznačajnije mesto, a tako će ostati i u budućnosti. Od umešnosti zaposlenih zavisi kvalitet usluga, a time i zadovoljstvo klijenata i njihova lojalnost (Vlahović, 2007). Dobro organizovan sektor ljudskih resursa garantuje uspeh hotelskih preduzeća. Savremen pristup ljudskim resursima daje mogućnost da se hotelsko preduzeće brže i bolje kotira na tržištu. Tako je Baum(1995) dao tabelu koja pokazuje pet klastera starih i novih pogleda na HR.

Savremeno poslovanje u hotelijerstvu nameće menadžmentu visoke ciljeve koji se mogu ostvariti jedino ako se promeni odnos prema ljudskim resursima.

Velika je razlika u pogledu starog i novog odnosa HR. Zastarela shvatanja HR stavljaju u podređen položaj, u smislu nikakve ili male brige za zaposlene, a oni su veza sa klijentima, pa se napredak ne može očekivati ni u kom pogledu. Nijedan 
Istrašivanja u oblasti zapošljavanja

Veliki promet radnika.

Ad hok zapošljavanje bez dugoročnih planova i vizija.

Zapošljavanje bez predhodne obuke, velika fluktuacija radne snage i/iz

drugih kompanija.

Bez interesa za iznalaženje ključa u smanjenju fluktuacije radnika.
Pažljiva analiza ponude radne snage iz lokalne zajednice i dugoročna saradnja sa tržištem rada.

Zaposleni se pažljivo biraju na osnovu kriterijuma koji su stvoreni empirijski i naučno.

Velika fluktacija doživljava se kao problem u funkcionisanju kompanije.

Poslovno napredovanje i razvoj karijere

Nejasni kriterijumi za unapredjenje, Sezonski radnici se ne obučavaju i ne prolaze trening.

Pomeranje u hirearhiji se doživljava kao ne lojalnost kompaniji.

Mogućnosti u napredovanju su ograničene za žene, manjine i ljude sa invaliditetom.
Planiranje i praćenje karijere svakog zaposlenog.

Razvoj zaposlenog u saradnji sa lokalnom zajednicom.

Sezonski i povremeni radnici se aktivno uključuju u sve oblike treninga.

Jednaka prava za napredak svih zaposlenih.

Nagrade i koristi

Kompanije nude minimalne nagrade.

Nepostojanje bonova niti drugih olika novčane stimulacije ili su oni neadekvatni.
Dobro razvijena skala nagradjivanja i stimulisanja.

Ugovori o dodatnim benificijama i učešće u deobi dobiti.

Obrazovanje, treninzi i razvoj

Treninzi i obuka nisu planirani, nego se dešavaju od slučaja do slučaja. Stariji zaposleni ne učestvuju u obukama.

Jaz između obrazovnog i direktnog rada u sektoru.

Obuke su izolovane.
Planirane politike treninga i obuke. Treninzi se promovišu od strane menadžmenta koji aktivno učestvuju.

Obuke su povezane sa napredovanjem u karijeri.

Partnerstvo između industrijskog i obrazovnog sektora.

Obrazovanje se zasniva na istraživanjima i potrebama.

Memadžment kultura

Autoritativna kultura zasnovana na staroj hirejarhiji odlučivanja i raspodele moći.

Zaposleni se tretiraju kao trošak. Zaposleni su daleko od procesa odlučivana i moći.

Zaposleni se doživljavaju kao prolazno osoblje.
Zaposleni se tretiraju kao osnovna snaga kompanije.

Participativna menadžment kultura koja se zasniva na demokratičnom načinu odlučivanja.

Vitalne odluke se donose i u skladu sa opštim interesom društvene zajednice.

Tabela 1. Prikaz tradicionalnih i savremenih sektora ljudskih resursa (HRM) u okviru hotelske industrije

Izvor: Mihić (2009)

klaster se ne može zanemariti niti nekom od njih dati prednost. Primena svih pet klastera na zaposlene zavisi od sposobnosti menadžmenta, a njihova implementacija može da bude vizija za budućnost hotelske kompanije. Vreme je faktor koji mora biti saveznik menadžmentu koji ima viziju za svoju kompaniju, jer su ljudski resursi najvrednija imovina koja pojedinačno i kolektivno doprinosi ostvarenju postavljenih ciljeva.

Uloga menadžmenta ljudskih resursa se ogleda u pravilnom organizovanju aktivnosti kompanije, da angažuje prave osobe na pravom mestu, da zaposleni imaju mogućnost za usavršavanje i napredak, da budu motivisani i nagrađivani i da pravilnom koordinacijom svih aktivnosti obavljaju svoj posao najbolje što mogu i ostvare najbolje rezultate za kompaniju (Đorđević-Boljanović, 2009).

Upravljanje ljudskim resursima u hotelijerstvu je dinamičan proces, zaposleni su na prvom, a gosti na drugom mestu. Od ljudskih resursa zavisi kvalitet usluga koje će biti pružene gostima, koje će dovesti do njihove satisfakcije i do željenih poslovnih rezultata kompanije (Vlahović, 2008).

Novo poslovno okruženje nameće nove izazove za zaposlene od kojih se očekuje da budu dobro edukovani, da ovladaju novim poslovnim veštinama, da budu vizionari, da misle i stvaraju, i da uz adekvatnu organizaciju poslovanja budu konkurentni na tržištu. "Kvalitet ljudskih resursa u turizmu i ugostiteljstvu ima posebnu dimenziju. Turistički radnik komunicira s potrošačima, od njega se zahteva ne samo obrazovanost i stručnost već i komunikativnost, ljubaznost, strpljivost, lični šarm, emocionalna stabilnost" (Čerović, 2011).

\section{ULOGA MENADŽERA U HOTELIJERSTVU}

Funkcija menadžera u hotelijerstvu je vrlo složena i specifična. Kako je hotelijerstvo uslužna delatnost, menadžer je spona između osoblja hotela i klijenata kao korisnika usluga. Klijent je uvek u pravu, i zahteva vrhunsku uslugu kako bi bio lojalan hotelu u kome odseda. Uloga menadžera je presudna u tom procesu.

Strategijsko planiranje u hotelskim preduzećima nije statički proces, pa nije moguće da jedna osoba donosi odluke za sve aspekte poslovanja. Odluke se donose na osnovu mišljenja velikog broja "specijalizovanih menadžera, zaduženih za posebna područja strategijskog planiranja i razvoja kao i za dostavljanje odgovarajućih informacija nižim jedinicama unutar organizacije" (Čačić, 2013). Zato menadžer mora da poseduje autoritet u skladu sa odgovornošću koja mu je data, jer se od njega očekuje da podstiče i vodi saradnike, a ne da naređuje i traži apsolutnu poslušnost. Hotelijerstvo zahteva dnevne aktivnosti, pa se od menadžera zahteva dobar odnos sa saradnicima u unutrašnjem i spoljnom okruženju, čime doprinosi efikasnijem poslovanju. Njegova odgovornost je velika, pa se svaka greška ili propust odražava direktno na kvalitet usluge i ima negativno odloženo dejstvo. Stepen uspešnosti menadžera u hotelijerstvu meri se na osnovu ostvarenog dnevnog učinka i načina delovanja. Od njega se očekuje da dobro vlada menadžerskim tehnikama i veštinama i da donosi odluke na bazi činjenica, a ne na osnovu subjektivnog iskustva. 
U savremenim uslovima poslovanja hotelskih organizacija, da bi menadžer bio dnevno uspešan, neophodno je da uskladi vlastito delovanje, uspostavi red u radu, primeni adekvatne postupke i metode rada, i definiše predviđeni vremenski okvir za sprovođenje pojedinih operacija. Rad menadžera je u najvećoj meri stvaralački, umni rad koji podrazumeva odlučnost, sposobnost, koncentraciju, inicijativu, optimizam i preduzetništvo (Petrović \& Petrović, 2013).

Zbog specifičnosti problematike kojom se bavi hotelijersto teorijski bi bilo dobro da menadžer ima osobinu da je dobar organizator, što znači da dobro poznaje svoj posao i da je dobar poznavalac ljudi sa kojima je u direktnoj komunikaciji. Praksa je pokazala da ove dve osobine retko ili nikada ne poseduje jedna osoba.

Menadžeri u hotelijerstvu imaju specifičnu ulogu, oni planiraju, donose odluke o strategiji i korišćenju ljudskih resursa. Oslanjajući se na sopstveni autoritet menadžeri uspostavljaju dobru komunikaciju zasnovanu na informacijama potrebnim za uspešnu realizaciju postavljenih ciljeva.

Komunikacija postaje važan deo stvaralačke aktivnosti ljudskih resursa u davanju i razmeni informacija. Ona je nepohodna i značajna za sprovođenje ciljeva u hotelijerstvu. Od velike je važnosti za menadžere, jer povezuje menadžerske aktivnosti u vođenju, organizovanju i kontrolisanju svih procesa u hotelijerstvu. Menadžer mora da bude vrlo vešt u komunikaciji, jer to nije obična razmena reči među sagovornicima, već razmena ideja, i vrlo je važno na koji način se ta komunikacija obavlja kako primaoc poruke ne bi bio u nedoumici. U hotelijerstvu je to veoma bitno, jer komunikacija između menadžera i zaposlenih nije nimalo jednostavna, ukoliko je cilj uspešno vođenje ljudima, a menadžeri imaju glavnu ulogu u razmeni pravih informacija.

Kako je hotelijerstvo uslužna delatnost, organizaciona kultura utiče na donošenje strateških odluka u smislu prilagođavanja okruženju, usmerenju zaposlenih ka kontroli, i smanjenju konflikata, a ukorenjene navike i zastareli sistem vrednosti može da uspori efikasno upravljanje hotelima. U savremenim uslovima poslovanja jedan od preduslova za uspeh jeste posvećenost organizacionoj kulturi kao važnom segmentu koji utiče na odabir strategije i poslovni ishod kompanije. Uspešnost na tržištu u odnosu na konkurenciju zavisi od načina na koji zaposleni obavljaju poslovnu aktivnost, a mnogo manje od organizacione strukture ili resursa kojima raspolažu.

\section{REZULTATI ISTRAŽIVANJA I DISKUSIJA}

Za hotelijerstvo, kao uslužnu delatnost, ljudski resursi predstavljaju najvažniji faktor za uspešno poslovanje i opstanak na tržištu. Sproveli smo istraživanje u beogradskim hotelima sa kategorijom tri i četiri zvezdice. Anketa se sastojala od 16 pitanja, a učestvovao je 61 zaposleni.

Grafik 1 i grafik 2 pokazuju da je zaposleno $51 \%$ muškaraca i $49 \%$ žena. Starosnu strukturu čine: zaposleni između 25 i 35 godina (30\%), zaposleni između 35 i 45 godina (57\%) i zaposleni između 45-55 godina (13\%). Možemo reći da je zaposleno više muškaraca nego žena, čija je starosna dob od 35 do 45 godina (57\%). Na grafikonu 3 vidimo da ima više žena čija je starosna dob od 25 do 30 godina, i više muškaraca od 35 do 45 godina. Što se može objasniti činjenicom da se žene posle 35. godine više vremena posvećuju porodici.

Za kvalitetno obavljanje svih zadataka u hotelijerstvu vrlo je važno obrazovanje zaposlenih, jer samo obrazovani kadar sa uspehom može da ispuni sve zahteve koji se postavljaju. Broj zaposlenih sa srednjom školom je $8,19 \%$, visokom i višom $73,77 \%$, a sa magistraturom i masterom $16,39 \%$. Može se reći da je kvalifikaciona struktura zaposlenih izuzetno dobra, i da menadžment hotela sa tri i četiri zvezdice vodi računa o obrazovanju svojih kadrova koji zauzimaju više pozicije u strukturi radnih mesta. Za profesionalno obavljanje poslova i formiranje tima stručnjaka, savremeni menadžment ljudskih resursa akcenat stavlja na obrazovanje zaposlenih, jer je to jedini način za uspešno rešavanje izazova koji se pred njih postavljaju.

POL

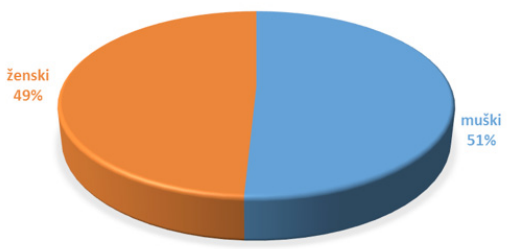

Grafik 1

GODINE

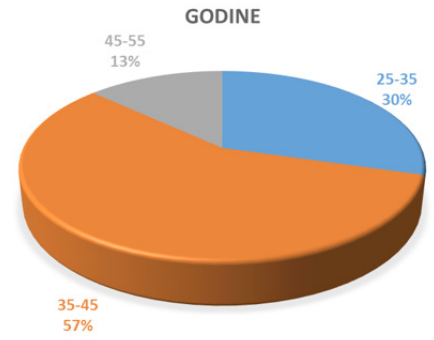

Grafik 2

GODINE - POL

25

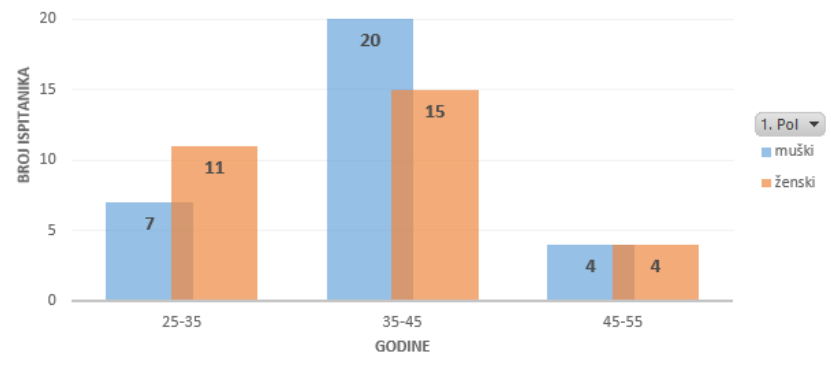

Grafik 3

Isto tako veoma je važno da li je obrazovanje koje poseduju zaposleni, vezano za posao koji obavljaju, pa su rezultati ankete pokazali da je 72,13\% zaposlenih ima obrazovanje koje je direktho vezano za turizam i ugostiteljstvo, a 22,29\% nije direktno vezano, što predstavlja visok stepen usklađenosti između zahteva posla koji obavljaju sa profilom obrazovanja koji poseduju. Kod učesnika u anketi nije bilo dokvalifikacije ili prekvalifikacije za radno mesto na kome se nalaze.

Što se tiče radnog iskustva, iz istraživanja se može zaključiti da do 5 godina u hotelijerstvu radi 14,75\% ispitanika, od 5 do 10 godina $67,21 \%$, a preko 10 godina $13,11 \%$. Može se reći da većina zaposlenih poseduje radno iskustvo koje doprinosi boljem izvršenju radnih zadataka.

Poznavanje svetskih jezika je veoma bitno za hotele sa tri i četiri zvezdice zbog komunikacije sa klijenatima koji posećuju hotele. Jedan od osnovnih uslova, od najnižih do najviših pozicija, za uspešno obavljanje poslova je poznavanje stranih jezika. Utvrdili smo da $73,77 \%$ zaposlenih u hotelima sa tri ili 
četiri zvezdice govori jedan strani jezik, i to engleski, a 26,23\% dva strana jezika. Iz dobijenih odgovora može se zaključiti da svi zaposleni govore najmanje jedan strani jezik.

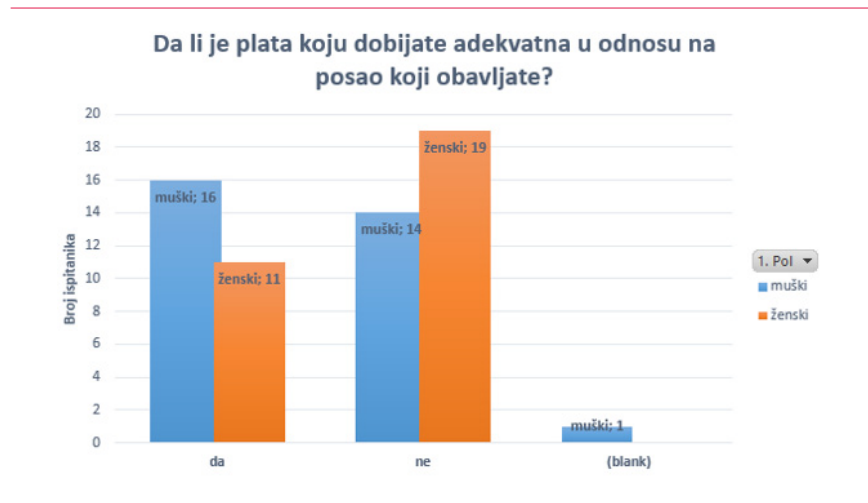

Grafik 4

Pitanje zarade u hotelijerstvu je kompleksno i odgovori su očekivani. Na grafikonu se može videti da $55 \%$ ispitanika nije zadovoljno zaradom, od toga 57,57\% čine žene, a 42,42\% čine muškarci. Može se zakljućiti da su za obavljanje istog posla žene manje plaćene od muškaraca. Ovom problemu bi se trebalo posebno posvetiti, u smislu zauzimanja stava koji će vrednovati radno mesto, nezavisno od pola zaposlenog. Niske zarade u ovoj delatnosti su evidentne. Uzroci su brojni, ali jedan od glavnih je niska akumulativna i reproduktivna sposobnost delatnosti. Posledice se ogledaju u velikoj fluktuaciji radne snage, neatraktivnosti zanimanja u hotelijerstvu, odsustvu motivacije zaposlenih i neučestvovanju u odlučivanju prilikom donošenja novih rešenja. Niske zarade su veliki problem u zadržavanju obrazovane i stručne radne snage u hotelijerstvu. Fluktacija radne snage stvara dodatne troškove hotelskim kompanijama, kojima je za obuku novih radnika potrebno dodatno vreme koje umanjuje produktivnost.

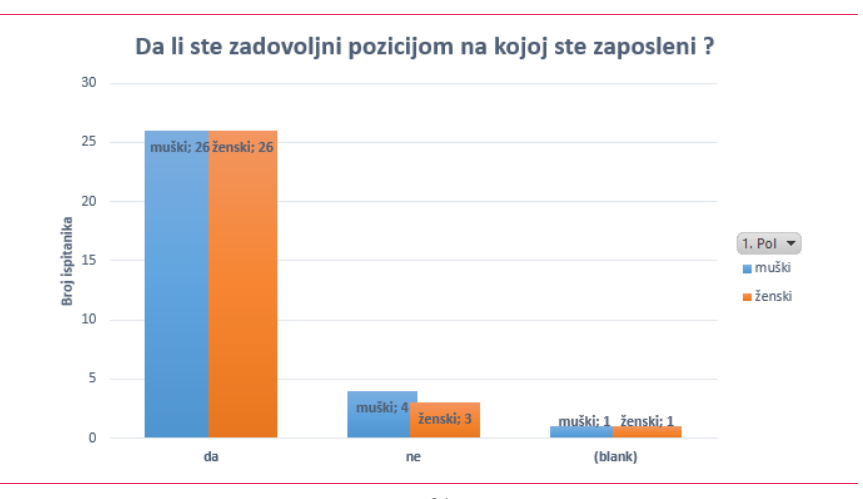

Grafik 5

Za svakog zaposlenog veoma je bitno da li je zadovoljan pozicijom na kojoj radi. Naša anketa je pokazala da je procenat žena i muškaraca zadovoljnih svojim poslom 50,98\%, a da je procenat žena koje nisu zadovoljne pozicijom na kojoj su zaposlene $42,8 \%$, jer smatraju da bi na višoj poziciji mogle više da doprinesu uspehu hotela.

Za hotele je veoma važno da zaposleni permanentno uče i da se usavršavaju, kako bi stekli veštine i znanje neophodne za nove poslovne zadatke. Globalizacija svetske privrede nameće funkciji ljudskih resursa jačanje potrebe za znanjem kao i privlačenje talentovanih pojedinaca, pa obuka zaposlenih postaje sve značajnija aktivnost u okviru funkcije upravljanja ljudskim resursima. U našoj anketi čak $68,85 \%$ zaposlenih je imalo obuku u tajanju od jednog meseca, 22,95\% zaposlenih imalo je obuku do šest meseci, a nije imalo obuku 6,56\%. Nijedan anketirani hotel nije slao svoje zaposlene na obuku koja je trajala više od 6 meseci. Ovi podaci govore da naši menadžeri ne vode računa o viziji svojih hotela na duži rok, i da tako svoje zaposlene ne motivišu da se usavršavanjem pozicioniraju na viši nivo. Rezultati ankete pokazuju da je 52,38\% zaposlenih sa visokom stručnom spremom bilo na obuci u trajanju do mesec dana, $28,57 \%$ sa višom, magistri i masteri 7,14\% i 4,76\% zaposlenih sa srednjom stručnom spremom. Smatramo da je obuka od mesec dana kratak period da se zaposleni obuče u struci i daju dobre rezultate na svom radnom mestu.

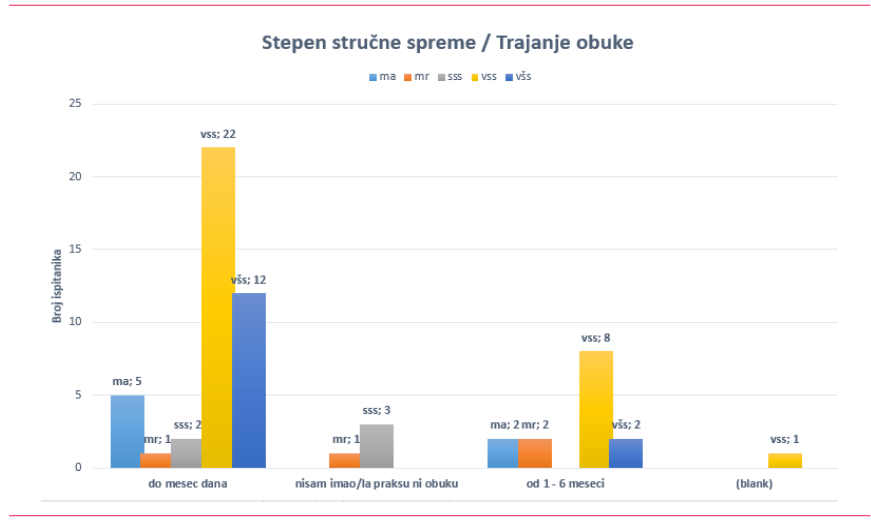

Grafik 6

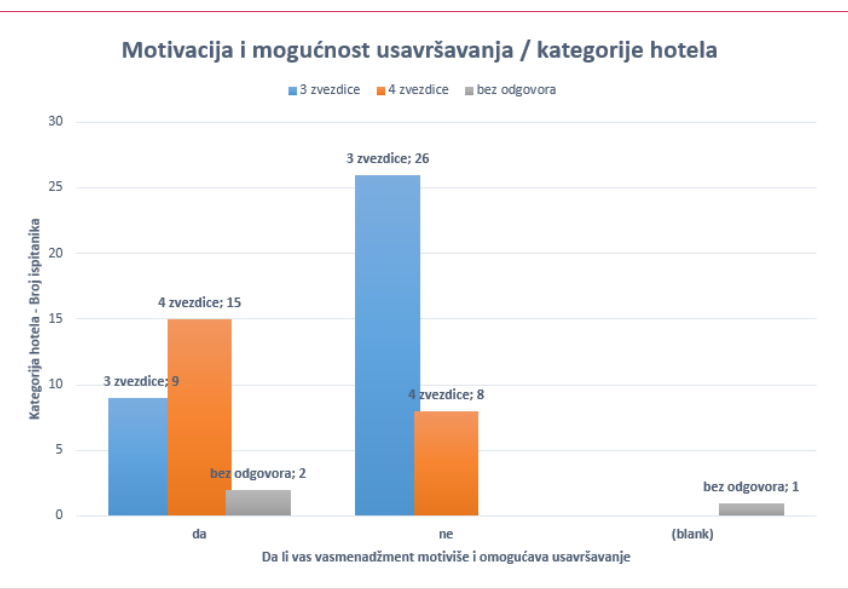

Grafik 7

Grafikon 7 pokazuje da hoteli sa kategorijom od tri i četiri zvezdice svojim zaposlenima ne pružaju dovoljnu mogućnost za usavršavanjem, što nije za pohvalu s obzirom na činjenicu da oni imaju klijente koji zahtevaju vrhunsku uslugu. Tako su anketirani sa 55,76\% odgovorili da nisu imali dodatno usavršavanje i to kod hotela sa tri zvezdice $76,47 \%$ i sa četiri zvezdice $23,53 \%$. Ispitanici koji su odgovorili, da su imali dodatno usavršavanje čine $42,62 \%$. U ovom slučaju hoteli sa četiri zvezdice učestvuju sa $57,69 \%$ a sa tri zvezdice $34,61 \%$. Ovi procenti mogu da daju pogrešnu sliku, pa se treba pozabaviti uzrocima ovako loše slike. Ovo isto govori da menadžment hotela nema viziju šta im treba u budućnosti za uspešno poslovanja, a osnova za uspešno poslovanje su kolektivni elementi u znanju, dok pojedinačna znanja ne predstavljaju veliku dobit za kompaniju. U biti zadatak menadžmenta je da održi intelektualnu imovinu. Međutim, naši menadžeri hotela imaju strah od radnika koji rade na znanju pa ništa ne preduzimaju da ih zadtže ili da im pomognu da rade efikasno, jer će oni zahtevati bolje radne uslove i bolju poziciju. Rezltati ankete potvrdjuju da menadžment nema sluha za kolektivno znanje koje je veoma važno za opstanak hotelskih kompanija na duži rok. 


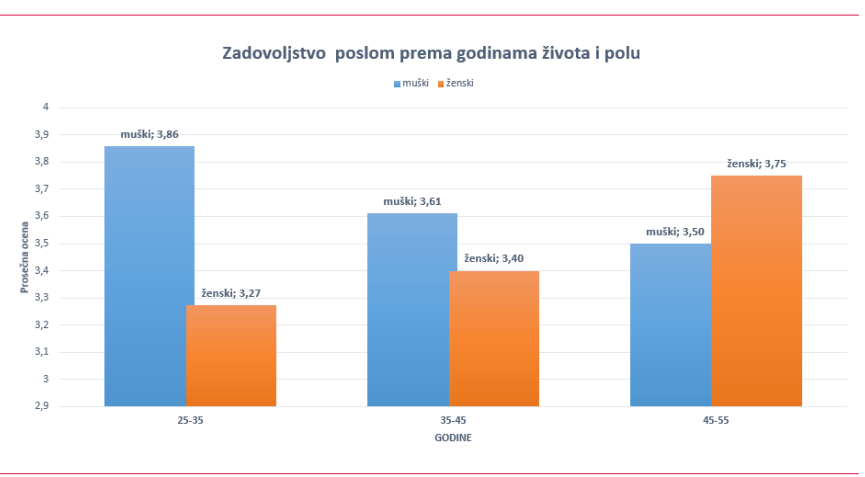

Gragik 8

Zadovoljstvo poslom koji obavljaju zaposleni od velike je važnosti ne samo za zaposlenog već i za ostvarivanje ciljeva cele kompanije, jer je zadovoljan radnik lojalan svojoj kompaniji. $\mathrm{U}$ anketi je rangirano zadovoljsto poslom ocenom od 1 do 5 . Rezultati ankete pokazuju da je 47,54\% zaposenih dalo ocenu 3, a 49,18\% ocenu 4. Ocenom 1, 2 i 5 niko nije od ispitanika ocenio zadovoljstvo poslom. Rezultati ankete o zadovoljstvu poslom, na osnovu pola i godina života prikazani su na grafikonu 8. Možemo da zaključimo da sa povećanjem godina života, kod muškog pola, opada zadovoljsto poslom koji obavljaju. Muškarci su zadovoljniji poslom u periodu od 25. do 35. godine, a najmanje su zadovoljni poslom od 45 . do 55 . godine. Iz navedenog se može zaključiti da su zaposleni, muškog pola na početku karijere veoma ambiciozni i spremi da uče sa željom da napreduju ka višim pozicijama u hotelu. Sa povećanjem godina starosti zadovoljstvo poslom opada. Kod ženskog pola, kriva zadovoljsta poslom je obrnuta. U mlađim godinama ona pada, da bi sa godinama rasla. To je i razumljivo s obzirom na to da su u mladosti žene posvećene porodici, da bi se kasnije posvetile karijeri.

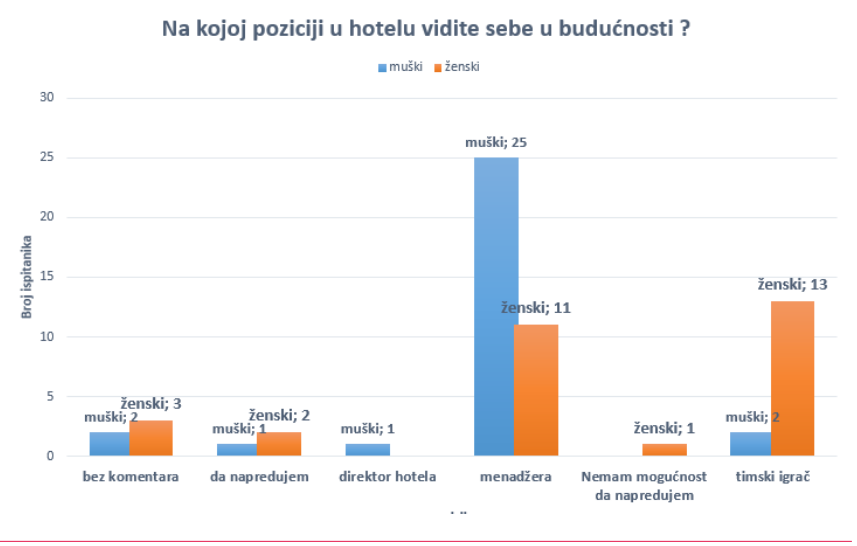

Grafik 9

Za svakog zaposlenog vrlo je važno na kojoj poziciji vidi sebe u budućnosti. Redosled koji je prirodan, nakon završenog obrazovanja u struci, obuke koje su imali u hotelu i stečenog iskustva, zaposleni s pravom očekuju bolju poziciju. Na grafikonu 9 možemo videti da je 55,73\% anketiranih odgovorilo da u budućnosti sebe vidi na poziciji menadžera hotela, od toga 71,43\% muškaraca, a 31,43\% žena. Po anketi, muški pol je zainteresovaniji za poziciju menadžera, dok žene radije biraju poziciju timskog igrača, od $21,31 \%$ opredeljenih za ovu poziciju, žene čine $86,66 \%$. Možemo da zaključimo da muški pol pretenduje poziciji menadžera hotela, zato što im ona daje moć koju mogu da koriste u ostvarivanju svojih ciljeva. Ako je ta moć usmerena ka uspešnom poslovanju hotela na tržištu i zadovoljstvu svih zaposlenih, onda ona opravdava svoju svrhu.
Neznatan broj ispitanika je odgovorio da želi poziciju direktora hotela ili unapređenje na bilo kojoj poziciji. Interesantan podak je da se nijedan ispitanik nije opredelio za pozicju lidera hotela.

Suštinski gledano lider nema formalnu poziciju u hotelu, on ima posebne lične karakteristike i stil kojim utiče na druge da rade i slede ga u ostvarenju zajedničkih ciljeva. On znalački uklapa pojedinačne interese sa interesima kompanije, inspiriše i motiviše sve one koji suprotno misle i prilagođava ih opštoj kulturi kompanije, čime utiče na kreiranje njenog identiteta. Možda zbog ovih karakteristika lidera, naši ispitanici sebe u budućnosti ne vide kao lidera hotela.

\section{ZAKLJUČAK}

Ljudski resursi predstavljaju ključni faktor uspeha u hotelskim kompanijama. Efekat poslovanja hotelskih kompanija visoke kategorije zavisi od efekata ljudskih resursa. Menadžment ljudkih resursa, naročito u hotelijerstvu, mora usmeriti sve svoje aktivnosti ka tome da podrži i prati poslovnu strategiju radi ostvarivanja ciljeva kompanije i sticanja konkurentske pozicije na tržištu.

Na osnovu ankete koja je sprovedena u beogradskim hotelima čija je kategorija tri i četiri zvezdice, došli smo do zaključka da je zaposleno nešto više muškaraca nego žena, da je vrlo povoljna starosna struktura, jer većina zaposlenih (57\%) ima između 25 i 45 godina, da 83,6\% čine zaposleni sa višom i visokom školom iz oblasti turizama i hotelijerstva, da govore dva strana jezika. Isto tako, anketa je pokazala da su zaposleni nezadovoljni platom za posao koji obavljaju, a menadžment hotela ih ne motiviše i ne pruža im mogućnost permanentnog usavršavanja u struci, i time ih sprečava da zauznu višu poziciju od one na kojoj su zaposleni, zato je fluktuacija radne snage neminovna.

Uloga menadžera u hotelijarstvu je veoma kompleksna i traži mnogo napora i znanja kako bi se objedinile sve funkcije vezane za poslovanje hotela. Zato je svakodnevni rad menadžera važan za dobro funkcionisanje rada hotela, jer loša organizacija i komunicija sa podređenima i pogrešne odluke dovode do neuspeha organizacije kojom rukovodi. Zato menadžer svojom organizovanošću mora da utiče na zaposlene, kako bi ostvrio pozitivne promene. Za uspeh je bitno brzo donošenje odluka, a da bi opstali na tržištu, u dužem vremenskom periodu, menadžeri moraju da budu sposobni da zadovolje potrebe sadašnjih i budućih korisnika hotelskih usluga. Dominantnu poziciju zauzeće zaposleni koji su spremni da uče u kontinuitetu i da svoje znanje primene u praksi. Samo sa takvim ljudskim resursima hotelske kompanije mogu da imaju dobre poslovne rezultate i da zauzmu dobru poziciju na tržištu.

\section{LITERATURA}

Barjaktarević, D. (2013). Upravljanje kvalitetom u hotelijerstvu. Beograd: Univerzitet Singidunum.

Braun, T. (1995). Managing Human Resources in the European Tourisam And Hospitality Industry: A strategic Approash. London: Chapman \& Hall.

Čačić, K. (2013). Poslovanje hotelskih preduzeća. Beograd: Univerzitet Singidunum.

Čerović, S.(2009). Srategijski menadžment u turizmu. Beograd: Univerzitet Singidunum.

Čerović, S. (2011). Upravljanje ljudskim resursima u hotelijerstvu. Beograd: Univerzitet Singidunum.

Đorđević Boljanović, J. (2009). Menadžment znanja. Beograd: Data Status. 
Mihić, S. (2009). Menadžment ljudskih resursa u hotelskim kompanijama Slovenije: Zbornik radova. Bijeljina: Sinergija.

Moutinho, L. (2005). Strategijski menadžment u turizmu. Zagreb: Masmedia.

Petrović, P. (2006). Preduzetnički menadžment u hotelijerstvu. Novi Sad: PMF.

Petrović, P., \& Petrović, J. (2013). Upravljanje promenama $i$ unapređivanje dnevnog menadžmenta $u$ hotelskoj industriji: Zbornik radova. Zlatibor: Hotelska kuća.
Stefanović, V., \& Blagojević, S. (2009). Menadžment ljudskih resursa u turizmu. Novi Sad: Prirodno matematički fakultet.

Vlahović, S.(2007). Upravljanje ljudskim resursima i njihova primena $u$ hotelijerstvu. Zbornik radova Edukacija zaposlenih u turizmu. Beograd: Univerzitet Singidunum.

Vlahović, S. (2008). Značaj kadrovske strukture za razvoj hotelske industrije Crne Gore: Zbornik radova. Zlatibor: Hotelska kuća, HOPES 